\title{
Acute Effects of Air Pollution on Hospital Admissions for Asthma, COPD, and Bronchiectasis in Ahvaz, Iran
}

This article was published in the following Dove Press journal:

International Journal of Chronic Obstructive Pulmonary Disease

\author{
Hanieh Raji (iD \\ Atefeh Riahi (D) ${ }^{2}$ \\ Seyed Hamid Borsi' \\ Kambiz Masoumi ${ }^{3}$ \\ Narges Khanjani ${ }^{4}$ \\ Kambiz AhmadiAngali ${ }^{5}$ \\ Gholamreza Goudarzi ${ }^{6}$ \\ Maryam Dastoorpoor (iD ${ }^{5}$ \\ 'Department of Internal Medicine, Air \\ Pollution and Respiratory Diseases \\ Research Center, Ahvaz Jundishapur \\ University of Medical Sciences, Ahvaz, \\ Iran; ${ }^{2}$ Air Pollution and Respiratory \\ Diseases Research Center, Ahvaz \\ Jundishapur University of Medical \\ Sciences, Ahvaz, Iran; ${ }^{3}$ Department of \\ Emergency Medicine, Air Pollution and \\ Respiratory Diseases Research Center, \\ Ahvaz Jundishapur University of Medical \\ Sciences, Ahvaz, Iran; ${ }^{4}$ Environmental \\ Health Engineering Research Center, \\ Kerman University of Medical Sciences, \\ Kerman, Iran; ${ }^{5}$ Department of \\ Biostatistics and Epidemiology, Air \\ Pollution and Respiratory Diseases \\ Research Center, Ahvaz Jundishapur \\ University of Medical Sciences, Ahvaz, \\ Iran; ${ }^{6}$ Department of Environmental \\ Health Engineering, Air Pollution and \\ Respiratory Diseases Research Center, \\ Ahvaz Jundishapur University of Medical \\ Sciences, Ahvaz, Iran
}

Correspondence: Maryam Dastoorpoor Department of Biostatistics and Epidemiology, Air Pollution and Respiratory Diseases Research Center, Ahvaz Jundishapur University of Medical Sciences, Ahvaz, Iran

Tel +986I 3336754

Email mdastoorpour@yahoo.com
Background and Aim: Although air pollution is a serious problem in Ahvaz, the association between air pollution and respiratory diseases has not been studied enough in this area. The aim of this study was to determine the relation between short-term exposure to air pollutants and the risk of hospital admissions due to asthma, COPD, and bronchiectasis in Ahvaz.

Methods: Hospital admissions data and air pollutants including $\mathrm{O}_{3}, \mathrm{NO}, \mathrm{NO}_{2}, \mathrm{SO}_{2}, \mathrm{CO}$, $\mathrm{PM}_{10}$, and $\mathrm{PM}_{2.5}$ were obtained from 2008 to 2018. Adjusted Quasi-Poisson regression with a distributed lag model, controlled for trend, seasonality, weather, weekdays, and holidays was used for data analysis.

Results: The results showed a significant increase in hospital admissions for asthma $(\mathrm{RR}=1.004,95 \% \mathrm{CI}: 1.002-1.007)$ and COPD (RR=1.003, 95\% CI: 1.001-1.005) associated with $\mathrm{PM}_{2.5}$. $\mathrm{PM}_{10}$ was associated with increased hospital admissions due to bronchiectasis in both genders (Men: RR=1.003, 95\% CI: 1.001-1.006) (Female: RR=1.003, 95\% CI: 1.000 1.006). $\mathrm{NO}_{2}$ was also associated with an increased risk of hospital admissions for asthma $(\mathrm{RR}=1.040,95 \% \mathrm{CI}: 1.008-1.074)$ and $\mathrm{COPD}(\mathrm{RR}=1.049,95 \% \mathrm{CI}: 1.010-1.090) . \mathrm{SO}_{2}$ was associated with the risk of hospital admissions of asthma ( $R R=1.069,95 \%$ CI: $1.017-1.124)$ and bronchiectasis $(\mathrm{RR}=1.030,95 \% \mathrm{CI}: 1.005-1.056)$. Finally, $\mathrm{CO}$ was associated with COPD (RR=1.643, 95\% CI: 1.233-2.191) and bronchiectasis $(\mathrm{RR}=1.542,95 \% \mathrm{CI}: 1.035-$ 2.298) hospital admissions.

Conclusion: Short-term exposure to air pollutants significantly increases the risk of hospital admissions for asthma, COPD, and bronchiectasis in the adult and elderly population.

Keywords: air pollution, particulate matter, asthma, COPD, bronchiectasis

\section{Introduction}

Air pollution is one of the biggest environmental health hazards that affects most world countries. ${ }^{1}$ Air pollution causes more than $3 \%$ of years of life loss, globally which is significantly more than the previous forecast in $2000 .^{2}$ Studies have estimated that the years of life lost (DALYs) worldwide due to air pollution have been $141,456,000$ years, in 2013. According to a WHO report, at least 7 million people have died due to air pollution in $2012 .^{3}$ Also in 2012 , low-income and middle-income countries in Southeast Asia and the western Pacific region had the highest levels of air pollution. ${ }^{4}$

Air pollution is widely associated with respiratory diseases. ${ }^{5-7}$ The effects of air pollution on the respiratory system include increased respiratory symptoms, decreased lung function, and increased incidence of chronic cough and bronchitis. ${ }^{8,9}$ Epidemiological and clinical studies show that in children and adults, increased hospital 
admissions, lung diseases, lung cancer, ${ }^{10}$ bronchiectasis, ${ }^{11-14}$ respiratory infection, pulmonary embolism, asthma, ${ }^{2,6,15-18}$ and chronic obstructive pulmonary diseases (COPD) $)^{9,19-23}$ are affected by air pollution.

Globally, 334 million people suffer from asthma and it is the most common chronic childhood disease. Asthma affects $14 \%$ of children worldwide and it is on the rise. ${ }^{24}$ Over the past 30 years, evidence has shown that air pollution negatively affects the respiratory health of children with and without asthma. ${ }^{25}$ In the study done by Khreis et al, the relation between exposure to traffic-related air pollution and childhood asthma in Bradford, England, was evaluated. This study estimated that $15 \%$ to $33 \%$ of annual childhood asthma cases were related to urban air pollution. ${ }^{26}$

Also, a study by Bouazza et al, on children, in Paris, showed that there was a significant relation between exposure to air pollution especially particulate matter (PM) and exacerbations of asthma symptoms in children visiting the emergency department. ${ }^{27}$

Another study by Salimi et al, about long-term exposure to air pollution and hospitalization for respiratory diseases in Australia, showed that there was a weak but direct relation between exposure to air pollution and hospitalization for asthma. ${ }^{28}$

According to the American College of Lung Physicians (CHEST) report in 2018, 65 million people suffer from chronic obstructive pulmonary disease (COPD) and 3 million die each year, making it the third leading cause of death worldwide. ${ }^{24}$ COPD is expected to become the leading cause of death worldwide in the next 15 years (26). According to a WHO report in $2014,33 \%$ of deaths due to COPD are related to exposure to air pollution. ${ }^{4}$

A study by Brakema et al, in Kyrgyzstan, during 2015-2014 found that the prevalence of COPD was directly associated with moderate to high $\mathrm{PM}_{2.5}$ concentrations. ${ }^{29}$ Also, Phosri et al, found that there was a significant relation between exposure to $\mathrm{NO}_{2}, \mathrm{CO}, \mathrm{PM}_{10}$ and increased hospital admissions because of pneumonia, $\mathrm{COPD}$, and asthma in Bankok, Thailand; while $\mathrm{O}_{3}$ and $\mathrm{SO}_{2}$ were associated with hospital admission for COPD and asthma as well. ${ }^{30} \mathrm{~A}$ study by Gao et al performed in Beijing, China, showed that short-term exposure to $\mathrm{PM}_{2.5}$, $\mathrm{PM}_{10}, \mathrm{NO}_{2}, \mathrm{SO}_{2}$, and $\mathrm{CO}$ caused hospitalization due to COPD. $^{31}$

Air enters the lungs through bronchioles that contain very small glands that produce mucus secretions. These secretions keep the ducts moist and absorb dust and airborne germs. The inner walls of the bronchioles are covered with ciliates that circulate the external particles along with the mucosal secretions and drive them out from the pharynx. If the bronchioles get injured, they can no longer keep themselves clean and as a result, the mucus secretions accumulate in the bronchioles and overflow into adjacent tubes. In this way, the bronchioles are susceptible to infection by bacteria, resulting in inflammation, and lesions called bronchiectasis. Bronchiectasis can cause chronic cough, bloody sputum, lung abscess, lung infection, and septicemia. ${ }^{32,33}$

A study done by Garcia-Olivé et al, in Barcelona, Spain, between 2007 and 2015, found that $\mathrm{SO}_{2}, \mathrm{NO}, \mathrm{NO}_{2}, \mathrm{O}_{3}$ and $\mathrm{CO}$ were significantly associated with increased risk of hospital admissions due to exacerbation of bronchiectasis. ${ }^{14}$ A study by Zhao et al, in Dongguan, China, indicated that short-term exposure to $\mathrm{CO}$ increases the risk of asthma, bronchiectasis, pneumonia, and respiratory disease. ${ }^{11}$

Ahvaz is a major metropolis in Iran that has suffered from environmental problems such as air, water, ${ }^{34}$ and soil pollution for many years ${ }^{35}$ and recently sand storms have further devastated the people. ${ }^{36,37}$ Nowadays Ahvaz has twice the national average prevalence of asthma. ${ }^{38}$ The aim of this study was to determine the relation between short-term exposure to air pollution and hospital admissions for asthma, COPD, and bronchiectasis in Ahvaz during 2008 to 2018 .

\section{Methods}

This ecological time series study was conducted from March 2008 to March 2018 in Ahvaz, Iran. Outcome data for these 10 years, based on the tenth version of the International Classification of Diseases (ICD-10), including J45.9 for asthma, J44.1, and J44.9 for COPD and J47 for bronchiectasis.

There are 7 public and 12 private hospitals in Ahvaz. Outcome data were obtained from 2 large hospitals which were referral hospitals for respiratory diseases.

Daily data on air pollutants including carbon monoxide (Average $24 \mathrm{hrs} \mathrm{CO}, \mathrm{ppm}$ ), particles less than $2.5 \mu \mathrm{m}$ (Average $24 \mathrm{hrs} \mathrm{PM}_{2.5}, \mu \mathrm{g} / \mathrm{m}^{3}$ ), particles less than $10 \mu \mathrm{m}$ in diameter (Average $24 \mathrm{hrs} \mathrm{PM}_{10}, \mu \mathrm{g} / \mathrm{m}^{3}$ ), nitrogen dioxide (Average $24 \mathrm{hrs} \mathrm{NO}_{2}$, ppm), nitrogen monoxide (Average $24 \mathrm{hrs} \mathrm{NO}$, ppm), and sulfur dioxide (Average $24 \mathrm{hrs} \mathrm{SO}_{2}, \mathrm{ppm}$ ), and ozone (Average $24 \mathrm{hrs} \mathrm{O}_{3}, \mathrm{ppm}$ ), were inquired from March 2008 to March 2018, from the Khuzestan Province, Department of Environment. Air pollutants were measured in four stations located in different parts of Ahvaz. 
The average of daily mean levels of air pollutants, from all four stations were used as the pollution level for the whole city, in the statistical models. Meteorological data including daily temperature and relative humidity were inquired from the Khuzestan Meteorological Organization for the same period.

A time series regression model was used to investigate the relation between hospital admissions for asthma, COPD, and bronchiectasis; and air pollutants. ${ }^{39}$

When the dependent variable is a count, Poisson models from the generalized linear models (GLM) family are used. In this study, since the variance of the outcome variable was larger than the mean, a quasi-Poisson model was used. $^{40,41}$ So one the Quasi-Poisson model and distributed lag models were used to estimate the relation between the outcomes and exposure to air pollutants. In this study, the long-term trend, seasonality, relative humidity, temperature, and holidays (DOW) were adjusted in the final model. The effect of seasonality and long-term trend was adjusted through a flexible spline function of time with a degree of freedom of 7 per year. ${ }^{39}$ The effect of humidity and temperature was also controlled by a natural cubic spline function with 3 and 6 degrees of freedom, respectively. ${ }^{39,40,42}$

The distributed lag models were run from 0 to 7 days lag and risk ratios with 95\% confidence intervals were calculated for hospital admissions of asthma, COPD, and bronchiectasis for every 10 units increase in air pollutants. In order to avoid the co-linearity effect between air pollutants, models were run for each pollutant separately, using the adjusted unconstrained DLM models. ${ }^{40,43}$ Also, the relation between outcomes and exposure to air pollutants were calculated in age and gender groups. Analysis was performed using R.3.5.3 software and the level of significance was set at less than 0.05. Other details on the analysis methods can be found in similar previously published articles. ${ }^{41,44}$

\section{Results}

During the 10-year study period, the total number and average hospital admissions for asthma were 3090, and $0.8 \pm 1.8$; for COPD, it was 4534, and $1.2 \pm 1.7$ and for bronchiectasis, it was 1994, and 0.6 \pm 1.0 . The highest number of hospital admissions for asthma have been in people less than 60 years old (2508). But the highest number of hospital admissions for COPD (2909) and bronchiectasis (1007) were in $>60$ year olds.

Mean daily concentrations of $\mathrm{PM}_{10}$ and $\mathrm{PM}_{2.5}$ were 245.5 and $85.9 \mu \mathrm{g} / \mathrm{m}^{3}$, respectively, which have been higher than the United States Environmental Protection Agency's $24 \mathrm{hrs}$ standard in 1997 which is 150 and $65 \mu \mathrm{g} / \mathrm{m}^{3}$, respectively (Table 1). The time trend of ambient air pollutants during 2008-2018 has been shown in Figure 1.

Table 2 shows the Spearman correlations between air pollutants and meteorological parameters in Ahwaz. Some variables show significant statistical correlation.

Tables 3-5 show significant relation between exposure to $\mathrm{PM}_{2.5}, \mathrm{PM}_{10}, \mathrm{NO}, \mathrm{NO}_{2}, \mathrm{SO}_{2}, \mathrm{CO}$, and hospital admissions because for asthma, COPD, and bronchiectasis for up to 7 days after exposure.

\section{Association Between $\mathrm{PM}_{2.5}$ and Asthma, COPD, and Bronchiectasis}

There was a significant and direct relation between exposure to $\mathrm{PM}_{2.5}$ and hospital admissions for asthma in the general population, men, women, and people less and above 60 years old. And as per $10 \mu \mathrm{g} / \mathrm{m}^{3}$ increase in $\mathrm{PM}_{2.5}$, the risk of asthma hospital admissions in the total population increased significantly by $0.4 \%$ (lag 2 ), in men by $0.4 \%$ (lag 6$)$, in women by $0.6 \%$ (lag 2), and in $\leq 60$ years old (lag 2) and $>60$ years old by $0.5 \%$ (zero lag) (Table 3 ).

The results also showed that per $10 \mu \mathrm{g} / \mathrm{m}^{3}$ increase in $\mathrm{PM}_{2.5}$, the risk of COPD hospital admissions in the total population, both genders and $\leq 60$ years old, increased $0.3 \%, 0.3 \%$, and $0.4 \%$ at lag 2 , respectively (Table 4 ). On the other hand, per $10 \mu \mathrm{g} / \mathrm{m}^{3}$ increase in $\mathrm{PM}_{10}$, the risk of hospital admissions for bronchiectasis in men and women, increased $0.3 \%$ at lag 2 and 6 , respectively (Table 5).

\section{Association Between $\mathrm{NO}_{2}$ and Asthma and COPD}

$\mathrm{NO}_{2}$ was associated with the risk of hospital admissions for asthma in the total population, men, $\leq 60$ years old and $>60$ years old; and hospital admissions for COPD in women; and per $10 \mu \mathrm{g} / \mathrm{m}^{3}$ increase in $\mathrm{NO}_{2}$, the risk of hospital admissions for asthma in the total population increased by $4 \%$ and $3.3 \%$ (in lag 1 and 3), in the male population by $5.2 \%$ (in lag 1), and in the $\leq 60$ years old by $4.2 \%$ (in lag 1 ) and $>60$ years old by $6.9 \%$ (lag 4). Hospital admissions due to COPD increased $4.9 \%$ after 4-day lags in the female population (Tables 3 and 4).

\section{Association Between NO and Asthma and COPD}

Exposure to NO was associated with the risk of hospital admissions for asthma in the total population, women and $>60$ years old, and the risk of hospital admissions for 
Table I The Number of Hospital Admissions Due to Asthma, COPD, and Bronchiectasis in Population Subgroups and Descriptive Statistics of Air Pollutants and Meteorological Parameters in Ahvaz City, 2008-2018

\begin{tabular}{|c|c|c|c|c|c|c|c|c|}
\hline Variable (Mean per Day) & $\mathbf{N}$ & Mean & SD & Min & Max & QI & Median & Q3 \\
\hline Total people/Asthma & 3090 & 0.8 & 1.8 & 0 & 29 & 0 & 0 & I \\
\hline Men/Asthma & 1513 & 0.4 & 1.2 & 0 & 18 & 0 & 0 & 0 \\
\hline Women/Asthma & 1577 & 0.4 & I.I & 0 & 18 & 0 & 0 & 0 \\
\hline$\leq 60$ years/Asthma & 2508 & 0.7 & 1.7 & 0 & 29 & 0 & 0 & I \\
\hline$>60$ years $/$ Asthma & 582 & 0.1 & 0.5 & 0 & 6 & 0 & 0 & 0 \\
\hline Total people/COPD & 4534 & 1.2 & 1.7 & 0 & 12 & 0 & I & 2 \\
\hline Men/COPD & 3166 & 0.9 & 1.4 & 0 & 12 & 0 & 0 & 2 \\
\hline Women/COPD & 1368 & 0.4 & 0.8 & 0 & 7 & 0 & 0 & 0 \\
\hline$\leq 60$ years/COPD & 1625 & 0.3 & 0.7 & 0 & 6 & 0 & 0 & 0 \\
\hline$>60$ years/COPD & 2909 & 0.8 & 1.3 & 0 & 12 & 0 & 0 & I \\
\hline Total people/Bronchiectasis & 1994 & 0.6 & 1.0 & 0 & 8 & 0 & 0 & I \\
\hline Men/Bronchiectasis & 918 & 0.3 & 0.7 & 0 & 6 & 0 & 0 & 0 \\
\hline Women/Bronchiectasis & 1076 & 0.3 & 0.7 & 0 & 6 & 0 & 0 & 0 \\
\hline$\leq 60$ years/Bronchiectasis & 987 & 0.3 & 0.7 & 0 & 6 & 0 & 0 & 0 \\
\hline$>60$ years/Bronchiectasis & 1007 & 0.3 & 0.7 & 0 & 8 & 0 & 0 & 0 \\
\hline $\mathrm{O}_{3}\left(\mu \mathrm{g} / \mathrm{m}^{3}\right)$ & - & 70.5 & 188.6 & 0.04 & 6520.0 & 26.4 & 42.7 & 64.6 \\
\hline $\mathrm{PM}_{2.5}\left(\mu \mathrm{g} / \mathrm{m}^{3}\right)$ & - & 85.7 & 150.4 & 0.57 & 3938 & 35.9 & 52.7 & 81.2 \\
\hline $\mathrm{PM}_{10}\left(\mu \mathrm{g} / \mathrm{m}^{3}\right)$ & - & 216.9 & 278.3 & 1.8 & 4324.2 & 105.8 & 149.2 & 222.4 \\
\hline $\mathrm{NO}_{2}\left(\mu \mathrm{g} / \mathrm{m}^{3}\right)$ & - & 46.4 & 43.1 & 1.5 & 443.8 & 17.8 & 35.6 & 60.7 \\
\hline $\mathrm{NO}\left(\left(\mu \mathrm{g} / \mathrm{m}^{3}\right)\right)$ & - & 29.1 & 31.0 & 0.12 & 608.7 & 9.1 & 19.6 & 38.2 \\
\hline $\mathrm{CO}\left(\mu \mathrm{g} / \mathrm{m}^{3}\right)$ & - & 1.5 & 2.1 & 0.1 & 70.4 & 0.6 & 1.13 & 2.0 \\
\hline $\mathrm{SO}_{2}\left(\mu \mathrm{g} / \mathrm{m}^{3}\right)$ & - & 48.8 & 57.0 & 0.0 & 907.4 & 19.3 & 35.9 & 59.3 \\
\hline Temperature $\left({ }^{\circ} \mathrm{C}\right)$ & - & 27.0 & 9.4 & 1.4 & 47.8 & 18.4 & 27.7 & 36.0 \\
\hline Relative Humidity (\%) & - & 42.3 & 17.9 & 7.0 & 96.0 & 27.5 & 40.0 & 54.5 \\
\hline
\end{tabular}

COPD in the total population, men, women, and $>60$ years old and per $10 \mu \mathrm{g} / \mathrm{m}^{3}$ increase in NO, the risk of hospital admissions for asthma increased in the total population, by $2.5 \%$ in lag 1 , in the female population by $4.1 \%$ in lag 1 and in $>60$ years old by $6.5 \%$ and $5.7 \%$ in lag 1 and 3 , respectively. Also, in relation to $\mathrm{NO}$ and COPD hospital admissions, a $2.1 \%$ and $1.7 \%$ increase in lag 1 and 3 in the total population, $2 \%$ in lag 1 in the male population, $2.8 \%$ in lag 3 in the female population, as well as an $2.2 \%$ and $2 \%$ increase in lag 1 and 3 in population of $>60$ years old was observed (Tables 3 and 4).

\section{Association Between $\mathrm{SO}_{2}$ and Asthma and Bronchiectasis}

$\mathrm{SO}_{2}$ was associated with the risk of hospital admissions for asthma and bronchiectasis and per $10 \mu \mathrm{g} / \mathrm{m}^{3}$ increase in $\mathrm{SO}_{2}$, the risk of hospital admissions for asthma in people $>60$ years old, increased $6.9 \%$ in lag 2 . Also, per $10 \mu \mathrm{g} / \mathrm{m}^{3}$ increase in $\mathrm{SO}_{2}$, the risk of hospital admissions of bronchiectasis in the total population increased $3 \%$ and $2.7 \%$ in lag 1 and 4 , in the male population increased 5.4\% in lag
1 , in the female population $4.6 \%$ in lag 4 and in $>60$ years old $4.3 \%$ in lag 1 (Tables 3 and 5 ).

\section{Association Between CO and COPD and Bronchiectasis}

$\mathrm{CO}$ was associated with COPD and bronchiectasis hospital admissions and per $10 \mu \mathrm{g} / \mathrm{m}^{3}$ increase in $\mathrm{CO}$, the risk of hospital admissions for COPD in the female population increased $64.3 \%$ in lag zero. Also, per $10 \mu \mathrm{g} / \mathrm{m}^{3}$ increase in $\mathrm{CO}$ the risk of hospital admissions for bronchiectasis, increased in the total population by $54.2 \%$ in lag 4 , in the women population by $44.9 \%$ in lag zero and $82.2 \%$ in lag 4 and in the population $>60$ years old $100 \%$ in lag 4 (Tables 4 and 5).

There was no significant relation between exposure to $\mathrm{O}_{3}$ and hospital admissions for asthma, COPD, or bronchiectasis.

\section{Discussion}

In this study, a significant direct relation was observed between short-term exposure to $\mathrm{PM}_{2.5}, \mathrm{NO}, \mathrm{NO}_{2}, \mathrm{SO}_{2}$, 

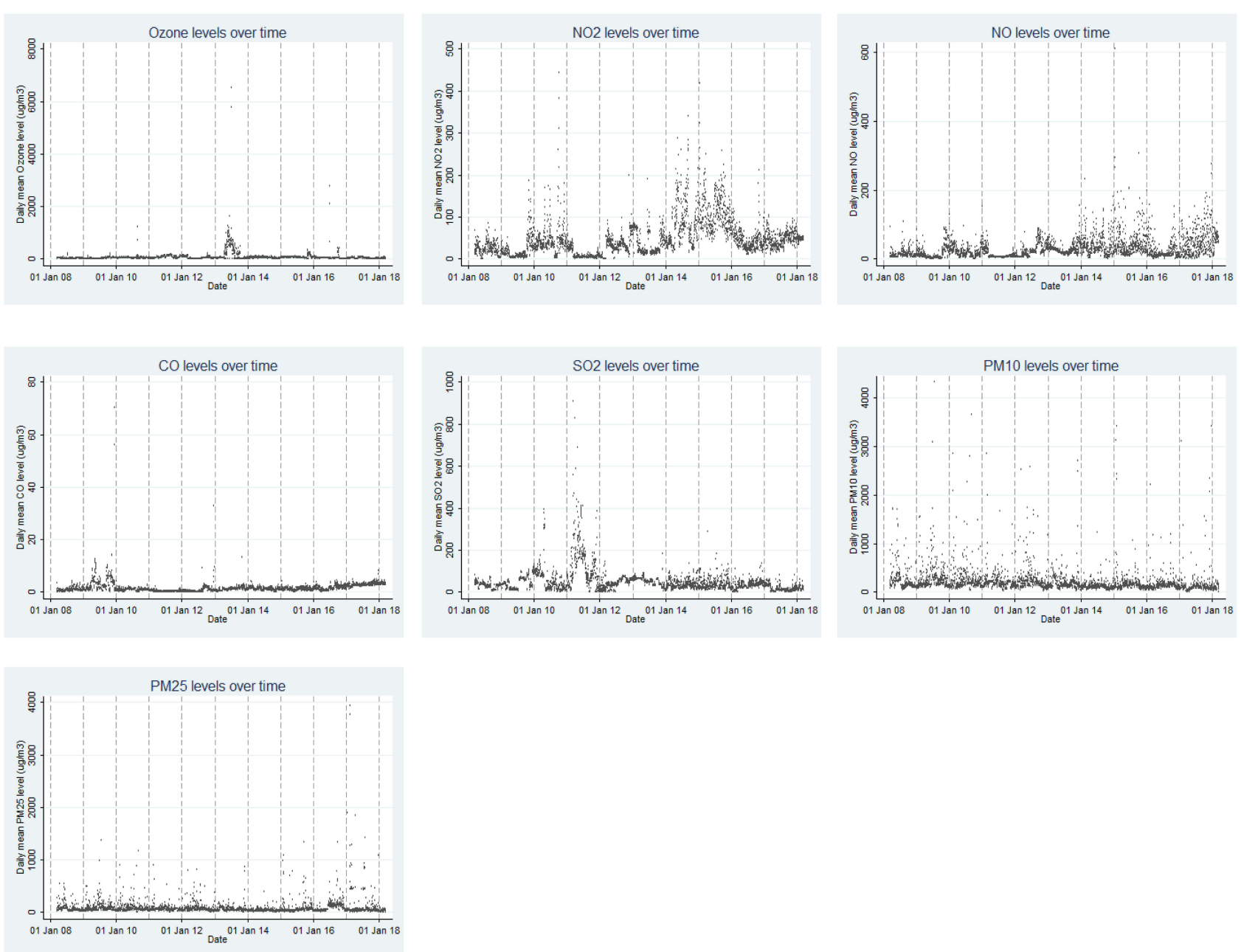

Figure I The average daily concentration of $\mathrm{O}_{3}, \mathrm{NO}_{2}, \mathrm{NO}, \mathrm{CO}, \mathrm{SO}_{2}, \mathrm{PM}_{10}$ and $\mathrm{PM}_{2.5}$ during the study period.

and hospital admissions due to asthma. This relation has been seen in many other studies as well. In China, exposure to air pollutants including $\mathrm{PM}_{2.5}, \mathrm{PM}_{10}, \mathrm{NO}_{2}$, and $\mathrm{SO}_{2}$ significantly increased the risk of hospital admissions for COPD and asthma, especially among women, children, and the elderly; ${ }^{45}$ and in Barcelona, Spain, high levels of $\mathrm{NO}_{2}$ were related with the number of asthma patients admitted to emergency departments and hospitals. ${ }^{7}$ Other Chinese studies showed that $\mathrm{PM}_{2.5}$ and $\mathrm{CO}$ were the major air pollutants that increased hospital admissions due to

Table 2 Correlation Coefficients Between Air Pollutants and Meteorological Parameters in Ahvaz, Between 2008 and 2018

\begin{tabular}{|c|c|c|c|c|c|c|c|c|c|}
\hline Variable & $\mathbf{O}_{3}$ & No & $\mathrm{NO}_{2}$ & $\mathrm{SO}_{2}$ & co & $\mathrm{PM}_{10}$ & $\mathbf{P M}_{25}$ & Temperature & Relative Humidity \\
\hline O3 & I & & & & & & & & \\
\hline NO & -0.03 & I & & & & & & & \\
\hline $\mathrm{NO} 2$ & 0.01 & $0.69 *$ & I & & & & & & \\
\hline $\mathrm{SO} 2$ & $0.25^{*}$ & -0.01 & $-0.13^{*}$ & 1 & & & & & \\
\hline $\mathrm{CO}$ & $-0.23 *$ & $0.37^{*}$ & $0.29 *$ & $-0.26 *$ & I & & & & \\
\hline PMIO & -0.03 & $-0.20 *$ & $-0.22 *$ & $0.20 *$ & $-0.13^{*}$ & I & & & \\
\hline PM25 & $-0.11 *$ & $-0.16^{*}$ & $-0.18^{*}$ & $0.11 *$ & 0.02 & $0.75^{*}$ & I & & \\
\hline Temperature & $0.04 *$ & $-0.22 *$ & $-0.10 *$ & 0.01 & -0.04 & $0.27^{*}$ & $0.25 *$ & I & \\
\hline Relative humidity & -0.03 & $0.32 *$ & $0.24 *$ & -0.02 & $0.09 *$ & $-0.29 *$ & $-0.26 *$ & $-0.74 *$ & I \\
\hline
\end{tabular}

Note: *Statistically significant (P-value<0.05). 
Table 3 The Relative Risk (95\% Cls) of Asthma Admissions with an Increase of $10 \mu \mathrm{g} / \mathrm{M}^{3}$ in $\mathrm{PM}_{2.5}, \mathrm{NO}, \mathrm{NO}_{2}$ and $\mathrm{SO}_{2}$ According to Single Lag, Adjusted Unconstrained and Constrained DLM Models ${ }^{\mathrm{a}}$

\begin{tabular}{|c|c|c|c|c|c|}
\hline Respondents & Pollutant & Lag & $\begin{array}{l}\text { Lag Terms Model One at Time } \\
\text { RR }(95 \% \mathrm{Cl})\end{array}$ & $\begin{array}{l}\text { Adjusted Unconstrained DLM } \\
\text { RR }(95 \% \mathrm{Cl})\end{array}$ & $\begin{array}{l}\text { Adjusted Constrained DLM } \\
\mathbf{R R}(95 \% \mathrm{Cl})\end{array}$ \\
\hline \multirow[t]{24}{*}{ Total } & \multirow[t]{8}{*}{$\mathrm{PM}_{2.5}$} & 0 & $1.002(1.000-1.004)$ & $1.000(0.997-1.003)$ & $1.001(0.998-1.003)$ \\
\hline & & I & $1.000(0.997-1.003)$ & $0.998(0.995-1.002)$ & $1.002(1.000-1.004)$ \\
\hline & & 2 & $1.004(1.002-1.006)$ & $1.004(1.002-1.007)^{*}$ & $1.002(1.000-1.004)$ \\
\hline & & 3 & $1.002(0.999-1.004)$ & $1.003(1.000-1.006)$ & $1.000(0.999-1.001)$ \\
\hline & & 4 & $1.000(0.997-1.003)$ & $0.997(0.994-1.001)$ & $1.000(0.999-1.00 I)$ \\
\hline & & 5 & $1.000(0.997-1.003)$ & $0.999(0.996-1.002)$ & $1.000(0.999-1.001)$ \\
\hline & & 6 & $1.002(0.999-1.004)$ & $1.003(1.000-1.006)$ & $1.000(0.999-1.001)$ \\
\hline & & 7 & $1.000(0.997-1.003)$ & $0.998(0.995-1.002)$ & $1.000(0.999-1.001)$ \\
\hline & \multirow[t]{8}{*}{ NO } & 0 & $0.999(0.998-1.001)$ & $0.984(0.966-1.003)$ & $0.993(0.975-1.010)$ \\
\hline & & 1 & $1.000(0.999-1.002)$ & $1.025(1.005-1.045)^{*}$ & $1.000(0.989-1.010)$ \\
\hline & & 2 & $0.999(0.997-1.001)$ & $0.973(0.952-0.994)$ & $1.000(0.989-1.010)$ \\
\hline & & 3 & 1.001 (0.999-I.002) & $1.009(0.989-1.030)$ & $1.003(0.997-1.009)$ \\
\hline & & 4 & $1.001(1.000-1.003)$ & $1.016(0.997-1.035)$ & $1.003(0.997-1.009)$ \\
\hline & & 5 & $1.000(0.998-1.002)$ & $0.988(0.968-1.008)$ & $1.003(0.997-1.009)$ \\
\hline & & 6 & 1.001 (0.999-1.002) & $1.014(0.994-1.034)$ & $1.003(0.997-1.009)$ \\
\hline & & 7 & $1.000(0.998-1.002)$ & $0.992(0.974-1.010)$ & $1.003(0.997-1.009)$ \\
\hline & \multirow[t]{8}{*}{$\mathrm{NO}_{2}$} & 0 & $0.994(0.971-1.016)$ & $0.98 \mid(0.953-1.009)$ & $0.995(0.970-1.022)$ \\
\hline & & 1 & $1.000(0.978-1.022)$ & $1.040(1.008-1.074)^{*}$ & $0.996(0.981-1.011)$ \\
\hline & & 2 & $0.975(0.953-0.999)$ & $0.940(0.908-0.973)$ & $0.996(0.98 \mathrm{I}-1.01 \mathrm{I})$ \\
\hline & & 3 & $1.008(0.987-1.030)$ & $1.033(1.001-1.067)^{*}$ & $1.000(0.993-1.006)$ \\
\hline & & 4 & $1.010(0.988-1.031)$ & $1.025(0.993-1.057)$ & $1.000(0.993-1.006)$ \\
\hline & & 5 & $0.98 \mid(0.959-1.004)$ & $0.955(0.923-0.988)$ & $1.000(0.993-1.006)$ \\
\hline & & 6 & $0.997(0.975-1.019)$ & $1.008(0.975-1.042)$ & $1.000(0.993-1.006)$ \\
\hline & & 7 & $1.002(0.98 \mathrm{I}-1.024)$ & $1.002(0.976-1.030)$ & $1.000(0.993-1.006)$ \\
\hline \multirow[t]{16}{*}{ Male } & \multirow[t]{8}{*}{$\mathrm{PM}_{2.5}$} & 0 & $1.003(1.000-1.006)$ & $1.002(0.999-1.006)$ & $1.002(0.999-1.006)$ \\
\hline & & 1 & 1.001 (0.998-1.004) & $1.000(0.996-1.004)$ & $1.002(0.999-1.004)$ \\
\hline & & 2 & $1.004(1.001-1.006)$ & $1.004(1.000-1.007)$ & $1.002(0.999-1.004)$ \\
\hline & & 3 & $1.002(0.998-1.005)$ & $1.002(0.998-1.006)$ & $1.000(0.999-1.001)$ \\
\hline & & 4 & $0.997(0.993-1.002)$ & $0.993(0.987-0.999)$ & $1.000(0.999-1.001)$ \\
\hline & & 5 & $1.002(0.999-1.005)$ & $1.001(0.997-1.006)$ & $1.000(0.999-1.001)$ \\
\hline & & 6 & $1.004(1.00 \mathrm{I}-\mathrm{I} .007)$ & $1.004(1.00 \mathrm{I}-1.008)^{*}$ & $1.000(0.999-1.00 I)$ \\
\hline & & 7 & $1.000(0.996-1.004)$ & $0.997(0.992-1.002)$ & $1.000(0.999-1.001)$ \\
\hline & \multirow[t]{8}{*}{$\mathrm{NO}_{2}$} & 0 & $1.010(0.979-1.041)$ & $0.985(0.947-1.024)$ & $1.000(0.965-1.037)$ \\
\hline & & 1 & $1.024(0.995-1.054)$ & $1.052(1.007-1.099)^{*}$ & $1.007(0.987-1.028)$ \\
\hline & & 2 & $0.998(0.968-1.030)$ & $0.949(0.904-0.996)$ & $1.007(0.987-1.028)$ \\
\hline & & 3 & $1.021(0.992-1.05 I)$ & $1.045(0.999-1.093)$ & $1.002(0.993-1.011)$ \\
\hline & & 4 & $1.013(0.984-1.044)$ & $1.014(0.968-1.062)$ & $1.002(0.993-1.011)$ \\
\hline & & 5 & $0.983(0.952-1.016)$ & $0.960(0.914-1.008)$ & $1.002(0.993-1.011)$ \\
\hline & & 6 & $1.005(0.974-1.036)$ & $1.018(0.970-1.068)$ & $1.002(0.993-1.011)$ \\
\hline & & 7 & $1.004(0.973-1.036)$ & $0.998(0.959-1.039)$ & $1.002(0.993-1.011)$ \\
\hline \multirow[t]{6}{*}{ Female } & \multirow[t]{6}{*}{$\mathrm{PM}_{2.5}$} & 0 & $1.000(0.996-1.004)$ & $0.997(0.993-1.002)$ & $0.998(0.994-1.002)$ \\
\hline & & 1 & $0.996(0.99 \mid-1.002)$ & $0.994(0.988-1.000)$ & $1.002(1.000-1.005)$ \\
\hline & & 2 & $1.004(1.001-1.006)$ & $1.006(1.002-1.010)^{*}$ & $1.002(1.000-1.005)$ \\
\hline & & 3 & $1.002(0.999-1.005)$ & $1.004(0.999-1.008)$ & $1.000(0.998-1.001)$ \\
\hline & & 4 & $1.002(0.998-1.005)$ & $1.002(0.998-1.007)$ & $1.000(0.998-1.001)$ \\
\hline & & 5 & $0.994(0.988-1.000)$ & $0.993(0.986-1.000)$ & $1.000(0.998-1.00 I)$ \\
\hline
\end{tabular}

(Continued) 
Table 3 (Continued).

\begin{tabular}{|c|c|c|c|c|c|}
\hline Respondents & Pollutant & Lag & $\begin{array}{l}\text { Lag Terms Model One at Time } \\
\text { RR }(95 \% \mathrm{Cl})\end{array}$ & $\begin{array}{l}\text { Adjusted Unconstrained DLM } \\
\text { RR }(95 \% \mathrm{Cl})\end{array}$ & $\begin{array}{l}\text { Adjusted Constrained DLM } \\
\mathbf{R R}(95 \% \mathrm{Cl})\end{array}$ \\
\hline & & $\begin{array}{l}6 \\
7\end{array}$ & $\begin{array}{l}0.998(0.993-1.003) \\
1.001(0.997-1.004)\end{array}$ & $\begin{array}{l}0.999(0.993-1.004) \\
1.000(0.996-1.005)\end{array}$ & $\begin{array}{l}1.000(0.998-1.001) \\
1.000(0.998-1.001)\end{array}$ \\
\hline & NO & $\begin{array}{l}0 \\
1 \\
2 \\
3 \\
4 \\
5 \\
6 \\
7\end{array}$ & $\begin{array}{l}0.998(0.996-1.00 I) \\
I .000(0.998-1.002) \\
0.998(0.995-1.000) \\
I .00 I(0.999-1.003) \\
I .00 I(0.999-1.003) \\
I .00 I(0.999-1.003) \\
I .00 I(0.999-1.003) \\
I .000(0.998-1.002)\end{array}$ & $\begin{array}{l}0.969(0.944-0.994) \\
I .04 I(1.016-1.067)^{*} \\
0.954(0.927-0.982) \\
1.020(0.994-1.046) \\
I .006(0.982-1.032) \\
0.995(0.969-1.02 I) \\
I .008(0.983-1.033) \\
0.998(0.975-1.02 I)\end{array}$ & $\begin{array}{l}0.983(0.960-1.007) \\
0.999(0.986-1.013) \\
0.999(0.986-1.013) \\
1.003(0.996-1.010) \\
1.003(0.996-1.010) \\
1.003(0.996-1.010) \\
1.003(0.996-1.010) \\
1.003(0.996-1.010)\end{array}$ \\
\hline \multirow[t]{2}{*}{$\leq 60$ years } & $\mathrm{PM}_{2.5}$ & $\begin{array}{l}0 \\
1 \\
2 \\
3 \\
4 \\
5 \\
6 \\
7\end{array}$ & $\begin{array}{l}I .000(0.997-1.003) \\
I .000(0.996-1.003) \\
I .003(1.00 I-1.005) \\
I .002(0.999-1.005) \\
0.999(0.995-1.003) \\
I .000(0.997-1.003) \\
I .002(0.999-1.005) \\
I .001(0.998-1.004)\end{array}$ & $\begin{array}{l}0.999(0.995-1.002) \\
0.999(0.995-1.003) \\
1.005(1.001-1.008)^{*} \\
1.004(1.000-1.007) \\
0.996(0.992-1.000) \\
0.998(0.995-1.002) \\
I .003(0.999-1.006) \\
1.000(0.996-1.003)\end{array}$ & $\begin{array}{l}0.999(0.995-1.002) \\
I .002(I .000-1.004) \\
I .002(I .000-1.004) \\
I .000(0.999-1.00 I) \\
I .000(0.999-1.00 I) \\
I .000(0.999-1.00 I) \\
I .000(0.999-1.00 I) \\
I .000(0.999-1.00 I)\end{array}$ \\
\hline & $\mathrm{NO}_{2}$ & $\begin{array}{l}0 \\
1 \\
2 \\
3 \\
4 \\
5 \\
6 \\
7\end{array}$ & $\begin{array}{l}0.993(0.968-1.019) \\
0.996(0.971-1.022) \\
0.971(0.945-0.997) \\
1.010(0.986-1.035) \\
1.008(0.984-1.033) \\
0.977(0.951-1.003) \\
0.990(0.965-1.016) \\
0.997(0.973-1.022)\end{array}$ & $\begin{array}{l}0.98 \mathrm{I}(0.950-1.013) \\
\mathrm{I} .042(\mathrm{I} .005-1.08 \mathrm{I}) * \\
0.929(0.893-0.967) \\
\mathrm{I} .046(\mathrm{I} .009-1.084) \\
\mathrm{I} .017(0.98 \mathrm{I}-1.054) \\
0.958(0.922-0.996) \\
\mathrm{I} .000(0.963-1.038) \\
\mathrm{I} .005(0.975-1.037)\end{array}$ & $\begin{array}{l}0.997(0.968-1.027) \\
0.993(0.976-1.011) \\
0.993(0.976-1.011) \\
0.999(0.992-1.007) \\
0.999(0.992-1.007) \\
0.999(0.992-1.007) \\
0.999(0.992-1.007) \\
0.999(0.992-1.007)\end{array}$ \\
\hline \multirow[t]{3}{*}{$>60$ years } & $\mathrm{PM}_{2.5}$ & $\begin{array}{l}0 \\
1 \\
2 \\
3 \\
4 \\
5 \\
6 \\
7\end{array}$ & $\begin{array}{l}1.006(1.003-1.009) \\
0.999(0.993-1.005) \\
1.005(1.002-1.009) \\
1.001(0.996-1.006) \\
1.001(0.996-1.006) \\
0.998(0.992-1.005) \\
0.999(0.993-1.005) \\
0.992(0.982-1.002)\end{array}$ & $\begin{array}{l}1.005(1.00 I-1.009) * \\
0.993(0.983-1.002) \\
I .003(0.998-1.008) \\
I .001(0.994-1.009) \\
I .001(0.994-1.007) \\
I .000(0.993-1.008) \\
I .002(0.996-1.009) \\
0.990(0.980-1.00 I)\end{array}$ & $\begin{array}{l}I .006(1.002-1.009) \\
I .000(0.997-1.004) \\
I .000(0.997-1.004) \\
I .000(0.998-1.002) \\
I .000(0.998-1.002) \\
I .000(0.998-1.002) \\
I .000(0.998-1.002) \\
I .000(0.998-1.002)\end{array}$ \\
\hline & NO & $\begin{array}{l}0 \\
1 \\
2 \\
3 \\
4 \\
5 \\
6 \\
7\end{array}$ & $\begin{array}{l}0.998(0.995-1.002) \\
I .002(0.999-1.005) \\
I .000(0.996-1.003) \\
I .004(1.002-1.007) \\
I .002(0.999-1.005) \\
I .000(0.997-1.004) \\
I .00 I(0.998-1.005) \\
I .002(0.999-1.005)\end{array}$ & $\begin{array}{l}0.959(0.919-1.000) \\
1.065(1.026-1.106)^{*} \\
0.946(0.904-0.990) \\
1.057(1.019-1.095)^{*} \\
1.015(0.976-1.055) \\
0.974(0.931-1.018) \\
1.020(0.978-1.064) \\
1.009(0.974-1.046)\end{array}$ & $\begin{array}{l}0.979(0.942-1.018) \\
1.012(0.993-1.031) \\
1.012(0.993-1.031) \\
1.010(1.000-1.021) \\
1.010(1.000-1.021) \\
1.010(1.000-1.021) \\
1.010(1.000-1.021) \\
1.010(1.000-1.021)\end{array}$ \\
\hline & $\mathrm{NO}_{2}$ & $\begin{array}{l}0 \\
1 \\
2 \\
3\end{array}$ & $\begin{array}{l}1.006(0.965-1.049) \\
1.019(0.978-1.060) \\
0.996(0.953-1.040) \\
1.006(0.964-1.049)\end{array}$ & $\begin{array}{l}0.982(0.93|-| .037) \\
1.042(0.980-1.108) \\
0.974(0.913-1.040) \\
0.986(0.924-1.053)\end{array}$ & $\begin{array}{l}0.996(0.949-1.045) \\
1.005(0.978-1.033) \\
1.005(0.978-1.033) \\
1.005(0.993-1.016)\end{array}$ \\
\hline
\end{tabular}

(Continued) 
Table 3 (Continued).

\begin{tabular}{|c|c|c|c|c|c|}
\hline Respondents & Pollutant & Lag & $\begin{array}{l}\text { Lag Terms Model One at Time } \\
\text { RR }(95 \% \mathrm{Cl})\end{array}$ & $\begin{array}{l}\text { Adjusted Unconstrained DLM } \\
\text { RR }(95 \% \mathrm{Cl})\end{array}$ & $\begin{array}{l}\text { Adjusted Constrained DLM } \\
\mathbf{R R}(95 \% \mathrm{Cl})\end{array}$ \\
\hline & & $\begin{array}{l}4 \\
5 \\
6 \\
7\end{array}$ & $\begin{array}{l}1.026(0.988-1.067) \\
I .00 I(0.959-1.044) \\
1.019(0.980-1.06 I) \\
1.029(0.992-1.068)\end{array}$ & $\begin{array}{l}1.069(1.004-1.137)^{*} \\
0.950(0.89 I-1.012) \\
1.015(0.952-1.08 I) \\
1.009(0.959-1.062)\end{array}$ & $\begin{array}{l}1.005(0.993-1.016) \\
1.005(0.993-1.016) \\
1.005(0.993-1.016) \\
1.005(0.993-1.016)\end{array}$ \\
\hline & $\mathrm{SO}_{2}$ & $\begin{array}{l}0 \\
1 \\
2 \\
3 \\
4 \\
5 \\
6 \\
7\end{array}$ & $\begin{array}{l}1.012(0.972-1.054) \\
1.028(0.992-1.066) \\
1.049(1.014-1.085) \\
1.010(0.969-1.053) \\
1.000(0.956-1.045) \\
1.028(0.991-1.066) \\
1.032(0.997-1.069) \\
1.012(0.971-1.054)\end{array}$ & $\begin{array}{l}0.993(0.936-1.053) \\
1.005(0.942-1.072) \\
1.069(1.017-1.124)^{*} \\
0.986(0.924-1.052) \\
0.958(0.887-1.035) \\
1.040(0.978-1.106) \\
1.026(0.968-1.088) \\
0.985(0.931-1.04 I)\end{array}$ & $\begin{array}{l}0.986(0.937-1.038) \\
1.031 \\
1.0006-1.057) \\
1.031 \\
1.003(0.990-1.057) \\
1.003(0.990-1.016) \\
1.003(0.990-1.016) \\
1.003(0.990-1.016) \\
1.003(0.990-1.016)\end{array}$ \\
\hline
\end{tabular}

Notes: *Statistically significant. adjusted for trend, seasonality, temperature, relative humidity, weekdays, and holidays.

asthma; $\mathrm{NO}_{2}, \mathrm{CO}, \mathrm{PM}_{10}, \mathrm{PM}_{2.5}$, and $\mathrm{SO}_{2}$ exacerbated asthma symptoms ${ }^{16}$ and $\mathrm{NO}_{2}, \mathrm{O}_{3}, \mathrm{PM}_{10}$, and $\mathrm{PM}_{2.5}$ increased hospital admissions and asthma. ${ }^{6}$ Increase in hospital admissions for asthma has been significantly related to increase in $\mathrm{NO}_{2}$ concentrations in several other studies as well. ${ }^{2,15}$

Although in this study children were not evaluated separately, studies conducted in North America, show that exposure to air pollution has negative effects on children with asthma; 25 and in China, asthma symptoms exacerbated among children, by increased concentrations of $\mathrm{NO}_{2}, \mathrm{CO}, \mathrm{PM}_{10}, \mathrm{PM}_{2.5}$, and $\mathrm{SO}_{2} \cdot{ }^{15}$ Liu et al found that in Liaoning Province, China, every $10 \mu \mathrm{g} / \mathrm{m}^{3}$ increase in $\mathrm{NO}_{2}$ was associated with an increased risk of asthma in 6-13-year-old children. ${ }^{17}$

Researchers think $\mathrm{NO}_{2}$ stimulates the lungs and causes bronchitis and pneumonia; and $\mathrm{SO}_{2}$ in people with asthma, bronchitis and emphysema can cause severe respiratory problems and lung damage. ${ }^{2,16}$ Asthma is caused by inflammation of the airways and in response to stimuli including air pollutants. The most important mechanism that $\mathrm{NO}_{2}$ can create and exacerbate asthma is the peroxidation of cell membrane lipids and producing various-free radicals that generally reduce the structure and function of airways. ${ }^{46}$ In addition, exposure to $\mathrm{NO}_{2}$ can increase the release of inflammatory mediators such as interleukin- $8 .{ }^{47}$ $\mathrm{SO}_{2}$, also causes airway inflammation and bronchial spasm and airway obstruction fibrosis by increasing the $\beta$ tumor growth factor level and eosinophils. ${ }^{48}$

In this study, the effect of air pollution was adjusted for temperature. However, a study from Taiwan showed that exposure to $\mathrm{PM}_{2.5}$ increased hospital admissions for asthma more on warm days (more than $23^{\circ} \mathrm{C}$ ) than cold days (below $23^{\circ} \mathrm{C}$ ). ${ }^{49}$ The interactions between temperature and air pollution should be more thoroughly investigated in future studies.

Several studies confirm the results of our study that the effect of air pollution also depends on age group. A study from South Korea found that the effects of exposure to $\mathrm{PM}_{10}, \mathrm{CO}$, and $\mathrm{NO}_{2}$ were significantly different in different age groups. ${ }^{50}$

In this study, a significant and direct relation was observed between short-term exposure to $\mathrm{PM}_{2.5}, \mathrm{NO}_{2}, \mathrm{NO}, \mathrm{CO}$, and hospital admissions due to COPD in the total population, women, men, adults, and the elderly. Other studies have shown the significant effect of increased ambient $\mathrm{NO}_{2}$ with hospital admissions due to COPD or asthma in Shiraz, Iran; ${ }^{51}$ the Netherlands, ${ }^{20}$ and Italy. ${ }^{52}$ In Taiwan, increase in $\mathrm{PM}_{2.5}$ and $\mathrm{PM}_{10}$, increased hospital admissions for COPD, asthma, and pneumonia; ${ }^{19,53}$ and in Italy increase in $\mathrm{PM}_{10}$, increased the risk of hospitalization due to COPD in the whole year, and this effect was stronger in the warm season. ${ }^{52}$ A review estimated that each $10 \mu \mathrm{g} / \mathrm{m}^{3}$ increase in $\mathrm{PM}_{2.5}, \mathrm{NO}_{2}$ and $\mathrm{SO}_{2}$ was associated with a $2.5 \%, 4.2 \%$, and $1.2 \%$ increase in hospital admissions and COPD emergencies, respectively. ${ }^{54}$ And other reviews stated that exposure to $\mathrm{PM}_{2.5}, \mathrm{NO}_{2}$ and $\mathrm{SO}_{2}$ was significantly related to hospital admissions and COPD mortality; ${ }^{55}$ and short-term exposure to air pollutants including $\mathrm{NO}_{2}, \mathrm{CO}, \mathrm{SO}_{2}$, and particles including $\mathrm{PM}_{2.5}$ and $\mathrm{PM}_{10}$ were related to the exacerbation of COPD. ${ }^{56}$ Authors also found that $\mathrm{CO}$ had a greater impact on COPD in hot seasons. ${ }^{56}$ 
Table 4 The Relative Risk (95\% Cls) of COPD Admissions with an Increase of $10 \mu g / M^{3}$ in $\mathrm{PM}_{2.5}, \mathrm{NO}, \mathrm{NO}{ }_{2}$, and $\mathrm{CO}$ According to Single Lag, Adjusted Unconstrained and Constrained DLM Models ${ }^{\mathrm{a}}$

\begin{tabular}{|c|c|c|c|c|c|}
\hline Respondents & Pollutant & Lag & $\begin{array}{l}\text { Lag Terms Model One at Time } \\
\text { RR }(95 \% \mathrm{Cl})\end{array}$ & $\begin{array}{l}\text { Adjusted Unconstrained DLM } \\
\text { RR }(95 \% \mathrm{CI})\end{array}$ & $\begin{array}{l}\text { Adjusted Constrained DLM } \\
\mathbf{R R}(95 \% \mathrm{Cl})\end{array}$ \\
\hline \multirow[t]{16}{*}{ Total } & \multirow[t]{8}{*}{$\mathrm{PM}_{2.5}$} & 0 & $0.999(0.997-1.001)$ & $0.999(0.996-1.001)$ & $0.998(0.996-1.001)$ \\
\hline & & 1 & $1.000(0.998-1.002)$ & $1.000(0.997-1.002)$ & $1.001(1.000-1.003)$ \\
\hline & & 2 & $1.001(0.999-1.003)$ & $1.003(1.001-1.005)^{*}$ & $1.001(1.000-1.003)$ \\
\hline & & 3 & $1.001(0.998-1.003)$ & $1.001(0.999-1.003)$ & $1.000(0.999-1.00 I)$ \\
\hline & & 4 & $0.999(0.996-1.001)$ & $0.997(0.994-1.000)$ & $1.000(0.999-1.001)$ \\
\hline & & 5 & $1.000(0.997-1.002)$ & $1.000(0.997-1.003)$ & $1.000(0.999-1.00 I)$ \\
\hline & & 6 & $1.000(0.998-1.003)$ & 1.001 (0.998-1.004) & $1.000(0.999-1.001)$ \\
\hline & & 7 & $1.000(0.998-1.002)$ & $0.999(0.997-1.002)$ & $1.000(0.999-1.001)$ \\
\hline & \multirow[t]{8}{*}{ NO } & 0 & $1.000(0.999-1.001)$ & $0.994(0.980-1.008)$ & $1.001(0.989-1.014)$ \\
\hline & & I & $1.001(1.000-1.002)$ & $1.021(1.006-1.036)^{*}$ & $0.999(0.992-1.007)$ \\
\hline & & 2 & $0.999(0.998-1.000)$ & $0.974(0.957-0.991)$ & $0.999(0.992-1.007)$ \\
\hline & & 3 & $1.000(0.999-1.002)$ & $1.017(1.001-1.032)^{*}$ & $1.000(0.996-1.004)$ \\
\hline & & 4 & $1.000(0.999-1.001)$ & $0.993(0.977-1.009)$ & $1.000(0.996-1.004)$ \\
\hline & & 5 & $1.000(0.998-1.001)$ & $0.992(0.976-1.009)$ & $1.000(0.996-1.004)$ \\
\hline & & 6 & $1.000(0.999-1.002)$ & $1.006(0.992-1.022)$ & $1.000(0.996-1.004)$ \\
\hline & & 7 & 1.001 (0.999-1.002) & $1.001(0.987-1.014)$ & $1.000(0.996-1.004)$ \\
\hline \multirow[t]{16}{*}{ Male } & \multirow[t]{8}{*}{$\mathrm{PM}_{2.5}$} & 0 & $0.999(0.997-1.002)$ & $0.999(0.995-1.002)$ & $0.998(0.995-1.002)$ \\
\hline & & I & $1.000(0.997-1.002)$ & $0.999(0.996-1.002)$ & I.00I (0.999-I.003) \\
\hline & & 2 & $1.002(0.999-1.004)$ & $1.003(1.000-1.006)^{*}$ & $1.001(0.999-1.003)$ \\
\hline & & 3 & $1.001(0.998-1.003)$ & 1.001 (0.998-1.004) & $1.000(0.999-1.001)$ \\
\hline & & 4 & $0.999(0.997-1.002)$ & $0.998(0.995-1.001)$ & $1.000(0.999-1.001)$ \\
\hline & & 5 & $1.000(0.998-1.003)$ & 1.001 (0.998-1.004) & $1.000(0.999-1.001)$ \\
\hline & & 6 & $1.000(0.998-1.003)$ & $1.001(0.998-1.004)$ & $1.000(0.999-1.00 I)$ \\
\hline & & 7 & $1.000(0.997-1.003)$ & $0.999(0.996-1.002)$ & $1.000(0.999-1.00 I)$ \\
\hline & \multirow[t]{8}{*}{ NO } & 0 & $1.000(0.999-1.002)$ & $0.994(0.978-1.011)$ & $1.001(0.986-1.017)$ \\
\hline & & I & $1.001(0.999-1.002)$ & $1.020(1.002-1.039)^{*}$ & $0.998(0.989-1.008)$ \\
\hline & & 2 & $0.999(0.997-1.000)$ & $0.974(0.954-0.995)$ & $0.998(0.989-1.008)$ \\
\hline & & 3 & $1.000(0.998-1.001)$ & $1.011(0.991-1.030)$ & $0.998(0.993-1.003)$ \\
\hline & & 4 & $0.999(0.998-1.001)$ & $0.993(0.974-1.012)$ & $0.998(0.993-1.003)$ \\
\hline & & 5 & $0.999(0.998-1.001)$ & $0.988(0.968-1.008)$ & $0.998(0.993-1.003)$ \\
\hline & & 6 & $1.000(0.999-1.002)$ & $1.008(0.990-1.026)$ & $0.998(0.993-1.003)$ \\
\hline & & 7 & 1.001 (0.999-1.002) & $1.000(0.984-1.016)$ & $0.998(0.993-1.003)$ \\
\hline \multirow[t]{14}{*}{ Female } & \multirow[t]{8}{*}{ NO } & 0 & $1.000(0.998-1.003)$ & $0.995(0.97 I-1.019)$ & $1.002(0.980-1.025)$ \\
\hline & & I & 1.001 (0.999-1.003) & 1.021 (0.995-I.047) & $1.001(0.988-1.014)$ \\
\hline & & 2 & $1.000(0.997-1.002)$ & $0.973(0.945-1.003)$ & $1.001(0.988-1.014)$ \\
\hline & & 3 & $1.001(1.000-1.003)$ & $1.028(1.002-1.055)^{*}$ & $1.003(0.996-1.009)$ \\
\hline & & 4 & $1.000(0.998-1.002)$ & $0.993(0.966-1.020)$ & $1.003(0.996-1.009)$ \\
\hline & & 5 & $1.000(0.998-1.002)$ & $0.998(0.969-1.027)$ & $1.003(0.996-1.009)$ \\
\hline & & 6 & $1.000(0.998-1.002)$ & $1.004(0.978-1.032)$ & $1.003(0.996-1.009)$ \\
\hline & & 7 & 1.001 (0.999-1.003) & $1.001(0.977-1.026)$ & $1.003(0.996-1.009)$ \\
\hline & \multirow[t]{6}{*}{$\mathrm{NO}_{2}$} & 0 & $1.021(0.997-1.046)$ & $1.008(0.975-1.04 I)$ & $1.013(0.983-1.044)$ \\
\hline & & I & $1.023(0.999-1.047)$ & $1.02 I(0.98 I-I .06 I)$ & $1.004(0.987-1.022)$ \\
\hline & & 2 & $1.007(0.982-1.032)$ & $0.998(0.958-1.040)$ & $1.004(0.987-1.022)$ \\
\hline & & 3 & $1.007(0.982-1.033)$ & $0.972(0.933-1.014)$ & $1.005(0.998-1.012)$ \\
\hline & & 4 & $1.026(1.003-1.050)$ & $1.049(1.010-1.090)^{*}$ & $1.005(0.998-1.012)$ \\
\hline & & 5 & $1.012(0.987-1.037)$ & $0.986(0.947-1.027)$ & $1.005(0.998-1.012)$ \\
\hline
\end{tabular}

(Continued) 
Table 4 (Continued).

\begin{tabular}{|c|c|c|c|c|c|}
\hline Respondents & Pollutant & Lag & $\begin{array}{l}\text { Lag Terms Model One at Time } \\
\text { RR }(95 \% \mathrm{Cl})\end{array}$ & $\begin{array}{l}\text { Adjusted Unconstrained DLM } \\
\text { RR }(95 \% \mathrm{CI})\end{array}$ & $\begin{array}{l}\text { Adjusted Constrained DLM } \\
\operatorname{RR}(95 \% \mathrm{Cl})\end{array}$ \\
\hline & & $\begin{array}{l}6 \\
7\end{array}$ & $\begin{array}{l}1.011(0.986-1.036) \\
1.011(0.987-1.037)\end{array}$ & $\begin{array}{l}1.009(0.969-1.051) \\
1.001(0.967-1.035)\end{array}$ & $\begin{array}{l}1.005(0.998-1.012) \\
1.005(0.998-1.012)\end{array}$ \\
\hline & $\mathrm{CO}$ & $\begin{array}{l}0 \\
1 \\
2 \\
3 \\
4 \\
5 \\
6 \\
7\end{array}$ & $\begin{array}{l}\mathrm{I} .466(\mathrm{I} . \mathrm{I} 80-\mathrm{I} .822) \\
\mathrm{I} .072(0.740-1.55 \mathrm{I}) \\
0.759(0.396-1.455) \\
0.947(0.593-1.5 \mathrm{I} 5) \\
0.86 \mathrm{I}(0.503-1.473) \\
\mathrm{I} .038(0.697-1.544) \\
\mathrm{I} .149(0.83 \mathrm{I}-\mathrm{I} .590) \\
\mathrm{I} .06 \mathrm{I}(0.732-\mathrm{I} .539)\end{array}$ & $\begin{array}{l}I .643(1.233-2.19 I)^{*} \\
0.795(0.50 I-1.259) \\
0.744(0.355-1.56 I) \\
I .079(0.622-1.87 I) \\
0.870(0.463-1.635) \\
I .05 I(0.667-1.658) \\
I .203(0.78 I-1.852) \\
I .042(0.660-1.645)\end{array}$ & $\begin{array}{l}1.654(1.258-2.174) \\
0.772(0.538-1.108) \\
0.772(0.538-1.108) \\
1.055(0.910-1.222) \\
1.055(0.910-1.222) \\
1.055(0.910-1.222) \\
1.055(0.910-1.222) \\
1.055(0.910-1.222)\end{array}$ \\
\hline$\leq 60$ years & $\mathrm{PM}_{2.5}$ & $\begin{array}{l}0 \\
1 \\
2 \\
3 \\
4 \\
5 \\
6 \\
7\end{array}$ & $\begin{array}{l}0.997(0.992-1.002) \\
0.998(0.993-1.003) \\
1.001(0.998-1.005) \\
1.000(0.996-1.004) \\
0.996(0.991-1.001) \\
0.997(0.992-1.002) \\
1.000(0.996-1.004) \\
1.000(0.996-1.004)\end{array}$ & $\begin{array}{l}0.997(0.991-1.002) \\
0.998(0.993-1.003) \\
1.004(1.000-1.009)^{*} \\
1.001(0.996-1.006) \\
0.995(0.990-1.001) \\
0.999(0.994-1.004) \\
1.001(0.996-1.005) \\
0.999(0.995-1.004)\end{array}$ & $\begin{array}{l}0.996(0.99 I-1.00 I) \\
1.00 I(0.998-1.004) \\
1.00 I(0.998-1.004) \\
0.999(0.998-1.00 I) \\
0.999(0.998-1.00 I) \\
0.999(0.998-1.00 I) \\
0.999(0.998-1.00 I) \\
0.999(0.998-1.001)\end{array}$ \\
\hline$>60$ years & NO & $\begin{array}{l}0 \\
1 \\
2 \\
3 \\
4 \\
5 \\
6 \\
7\end{array}$ & 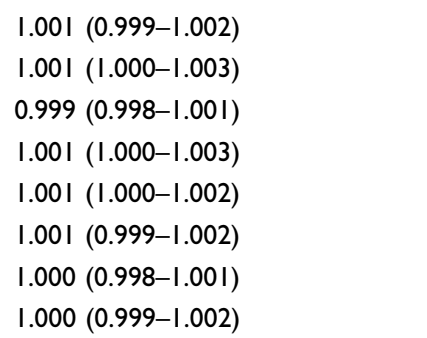 & $\begin{array}{l}0.999(0.983-1.016) \\
1.022(1.004-1.040)^{*} \\
0.972(0.951-0.993) \\
1.020(1.002-1.039)^{*} \\
1.000(0.983-1.019) \\
1.005(0.986-1.025) \\
0.994(0.975-1.014) \\
1.006(0.989-1.023)\end{array}$ & $\begin{array}{l}1.007(0.992-1.023) \\
1.000(0.99 I-1.009) \\
1.000(0.99 I-1.009) \\
1.003(0.998-1.008) \\
1.003(0.998-1.008) \\
1.003(0.998-1.008) \\
1.003(0.998-1.008) \\
1.003(0.998-1.008)\end{array}$ \\
\hline
\end{tabular}

Notes: *Statistically significant. ${ }^{\text {a} A d j u s t e d ~ f o r ~ t r e n d, ~ s e a s o n a l i t y, ~ t e m p e r a t u r e, ~ r e l a t i v e ~ h u m i d i t y, ~ w e e k d a y s, ~ a n d ~ h o l i d a y s . ~}$

In this study, there was a significant and direct relation between short-term exposure to $\mathrm{PM}_{10}, \mathrm{SO}_{2}, \mathrm{CO}$ and hospital admissions due to bronchiectasis. Studies from Barcelona, Spain, ${ }^{14}$ and Dongguan, China ${ }^{11}$ confirm these findings. The risk of exacerbation of bronchiectasis significantly increased in Dundee, with increase in $\mathrm{PM}_{10}$ and $\mathrm{NO}_{2}$, on the same day; and the effect of $\mathrm{NO}_{2}$, was stronger in spring. ${ }^{13}$ In Beijing, China, exposure to $\mathrm{PM}_{2.5}$, $\mathrm{PM}_{10}, \mathrm{NO}_{2}, \mathrm{SO}_{2}$, and $\mathrm{CO}$ was significantly related to increased admissions for upper respiratory tract infections, acute bronchitis, pneumonia, and acute bronchiectasis; and $\mathrm{PM}_{10}, \mathrm{SO}_{2}, \mathrm{CO}$, and $\mathrm{O}_{3}$ was also associated with outpatient admissions due to acute exacerbation of COPD and asthma. $^{12}$

Researchers think air pollutants have complex effects on the airways of respiratory patients, and cause inflammation, mucosal edema, and toxicity. PM can cause oxidative stress in the dendritic cells of the immune system and this exacerbates asthma. In addition, phagocytosis of damaged airway macrophage cells, which results in increased prostaglandin E2 levels, are other adverse effects of inhalation of carbon particles. The direct relation between $\mathrm{CO}$ and asthma is not clear. It seems that $\mathrm{CO}$ can exacerbate asthma through airway stimulation. ${ }^{18}$

One of the main mechanisms that explain the relation between exposure to air pollutants and COPD is oxidative stress. Oxidative stress can damage the airway epithelium and weaken the immune system. Air pollutants can also cause inflammation in the lungs and further decrease pulmonary function in COPD patients. The determinants of COPD exacerbation are still largely unknown. ${ }^{56}$

Although the mechanism of the effect of air pollutants on respiratory diseases is not fully understood, possible mechanisms include airway epithelial cell destruction, interference with cellular signaling pathways, destruction of lung parenchyma, various inflammatory responses, 
Table 5 The Relative Risk $\left(95 \% \mathrm{Cls}\right.$ ) of Bronchiectasis Admissions with an Increase of $10 \mu \mathrm{g} / \mathrm{M}^{3}$ in $\mathrm{PM} / 0$, so, and CO According to Single Lag, Adjusted Unconstrained and Constrained DLM Models ${ }^{\mathrm{a}}$

\begin{tabular}{|c|c|c|c|c|c|}
\hline Respondents & Pollutant & Lag & $\begin{array}{l}\text { Lag Terms Model One at Time } \\
\text { RR }(95 \% \mathrm{Cl})\end{array}$ & $\begin{array}{l}\text { Adjusted Unconstrained DLM } \\
\text { RR }(95 \% \mathrm{CI})\end{array}$ & $\begin{array}{l}\text { Adjusted Constrained DLM } \\
\mathbf{R R}(95 \% \mathrm{Cl})\end{array}$ \\
\hline \multirow[t]{16}{*}{ Total } & \multirow[t]{8}{*}{$\mathrm{SO}_{2}$} & 0 & $0.996(0.976-1.016)$ & $0.983(0.956-1.010)$ & $0.992(0.967-1.017)$ \\
\hline & & 1 & $1.009(0.992-1.027)$ & $1.030(1.005-1.056)^{*}$ & $1.006(0.993-1.020)$ \\
\hline & & 2 & $1.000(0.981-1.019)$ & $0.991(0.963-1.020)$ & $1.006(0.993-1.020)$ \\
\hline & & 3 & $0.999(0.980-1.019)$ & $0.984(0.954-1.014)$ & $1.002(0.996-1.007)$ \\
\hline & & 4 & $1.013(0.996-1.030)$ & $1.027(1.002-1.052)^{*}$ & $1.002(0.996-1.007)$ \\
\hline & & 5 & $1.007(0.988-1.025)$ & $0.997(0.970-1.026)$ & $1.002(0.996-1.007)$ \\
\hline & & 6 & $1.002(0.983-1.021)$ & $1.002(0.975-1.030)$ & $1.002(0.996-1.007)$ \\
\hline & & 7 & $0.997(0.978-1.017)$ & $0.995(0.970-1.020)$ & $1.002(0.996-1.007)$ \\
\hline & \multirow[t]{8}{*}{$\mathrm{CO}$} & 0 & $1.132(0.842-1.523)$ & $1.262(0.885-1.800)$ & $1.262(0.909-1.75 I)$ \\
\hline & & I & $0.972(0.656-\mid .44 I)$ & $0.977(0.613-1.557)$ & $0.913(0.688-1.213)$ \\
\hline & & 2 & $0.878(0.556-1.385)$ & $0.965(0.594-1.568)$ & $0.913(0.688-1.213)$ \\
\hline & & 3 & $0.889(0.567-1.394)$ & $0.746(0.484-1.148)$ & $1.020(0.909-1.145)$ \\
\hline & & 4 & $1.255(0.994-1.584)$ & $1.542(1.035-2.298)^{*}$ & $1.020(0.909-1.145)$ \\
\hline & & 5 & I.023 (0.724-I.443) & $0.792(0.462-1.357)$ & $1.020(0.909-1.145)$ \\
\hline & & 6 & $0.638(0.338-1.203)$ & $0.618(0.31 \mathrm{I}-1.230)$ & $1.020(0.909-1.145)$ \\
\hline & & 7 & $1.088(0.807-1.467)$ & $1.242(0.93|-| .657)$ & $1.020(0.909-1.145)$ \\
\hline \multirow[t]{16}{*}{ Male } & \multirow[t]{8}{*}{$P M_{10}$} & 0 & $1.002(0.999-1.004)$ & $1.002(0.999-1.005)$ & 1.001 (0.998-1.004) \\
\hline & & I & $1.000(0.997-1.003)$ & $0.999(0.995-1.002)$ & I.00I (0.999-I.003) \\
\hline & & 2 & $1.003(1.000-1.005)$ & $1.003(1.001-1.006)^{*}$ & $1.001(0.999-1.003)$ \\
\hline & & 3 & $0.997(0.992-1.001)$ & $0.996(0.99 I-1.00 I)$ & $0.998(0.997-1.000)$ \\
\hline & & 4 & $0.997(0.993-1.001)$ & $0.998(0.994-1.002)$ & $0.998(0.997-1.000)$ \\
\hline & & 5 & $0.999(0.996-1.003)$ & 1.001 (0.997-I.004) & $0.998(0.997-1.000)$ \\
\hline & & 6 & $0.998(0.994-1.002)$ & $0.999(0.995-1.003)$ & $0.998(0.997-1.000)$ \\
\hline & & 7 & $0.996(0.99 \mid-1.000)$ & $0.997(0.992-1.002)$ & $0.998(0.997-1.000)$ \\
\hline & \multirow[t]{8}{*}{$\mathrm{SO}_{2}$} & 0 & $0.990(0.960-1.021)$ & $0.958(0.919-1.000)$ & $0.978(0.94 I-1.016)$ \\
\hline & & I & $1.019(0.995-1.043)$ & $1.054(1.021-1.088)^{*}$ & $1.014(0.995-1.032)$ \\
\hline & & 2 & $0.999(0.97 \mid-1.028)$ & $0.990(0.951-1.031)$ & $1.014(0.995-1.032)$ \\
\hline & & 3 & $0.985(0.954-1.017)$ & $0.976(0.929-1.026)$ & $1.000(0.99 \mid-1.008)$ \\
\hline & & 4 & $0.998(0.969-1.027)$ & $1.002(0.959-1.046)$ & $1.000(0.991-1.008)$ \\
\hline & & 5 & $1.009(0.983-1.036)$ & $1.009(0.969-1.050)$ & $1.000(0.991-1.008)$ \\
\hline & & 6 & $1.015(0.990-1.040)$ & $1.026(0.993-1.06 I)$ & $1.000(0.991-1.008)$ \\
\hline & & 7 & $0.995(0.966-1.024)$ & $0.982(0.947-1.018)$ & $1.000(0.991-1.008)$ \\
\hline \multirow[t]{14}{*}{ Female } & \multirow[t]{8}{*}{$\mathrm{PM}_{10}$} & 0 & $1.000(0.997-1.003)$ & $0.999(0.996-1.003)$ & $1.000(0.996-1.003)$ \\
\hline & & I & $1.002(0.999-1.004)$ & $1.002(0.999-1.005)$ & 1.001 (0.999-I.003) \\
\hline & & 2 & $1.000(0.996-1.003)$ & $0.999(0.996-1.003)$ & I.00I (0.999-I.003) \\
\hline & & 3 & $0.999(0.996-1.003)$ & $0.999(0.995-1.003)$ & $1.000(0.999-1.001)$ \\
\hline & & 4 & $1.001(0.998-1.004)$ & $1.002(0.999-1.005)$ & $1.000(0.999-1.001)$ \\
\hline & & 5 & $0.998(0.995-1.002)$ & $0.996(0.99 \mid-1.000)$ & $1.000(0.999-1.001)$ \\
\hline & & 6 & $1.002(0.999-1.004)$ & $1.003(1.000-1.006)^{*}$ & $1.000(0.999-1.001)$ \\
\hline & & 7 & $1.000(0.997-1.003)$ & $1.000(0.997-1.003)$ & $1.000(0.999-1.00 I)$ \\
\hline & \multirow[t]{6}{*}{$\mathrm{SO}_{2}$} & 0 & $1.001(0.975-1.027)$ & $1.008(0.974-1.044)$ & $1.009(0.977-1.042)$ \\
\hline & & I & $1.002(0.976-1.028)$ & $1.005(0.965-1.046)$ & $0.999(0.980-1.018)$ \\
\hline & & 2 & $1.001(0.975-1.027)$ & $0.992(0.950-1.035)$ & $0.999(0.980-1.018)$ \\
\hline & & 3 & $1.009(0.985-1.034)$ & $0.99 I(0.95 I-I .032)$ & $1.003(0.996-1.011)$ \\
\hline & & 4 & $1.024(1.002-1.046)$ & $1.044(1.013-1.076)^{*}$ & $1.003(0.996-1.011)$ \\
\hline & & 5 & $1.005(0.979-1.031)$ & $0.994(0.958-1.032)$ & $1.003(0.996-1.011)$ \\
\hline
\end{tabular}

(Continued) 
Table 5 (Continued).

\begin{tabular}{|c|c|c|c|c|c|}
\hline Respondents & Pollutant & Lag & $\begin{array}{l}\text { Lag Terms Model One at Time } \\
\text { RR }(95 \% \mathrm{Cl})\end{array}$ & $\begin{array}{l}\text { Adjusted Unconstrained DLM } \\
\text { RR }(95 \% \mathrm{Cl})\end{array}$ & $\begin{array}{l}\text { Adjusted Constrained DLM } \\
\mathbf{R R}(95 \% \mathrm{Cl})\end{array}$ \\
\hline & & $\begin{array}{l}6 \\
7\end{array}$ & $\begin{array}{l}0.990(0.962-1.018) \\
1.001(0.975-1.027)\end{array}$ & $\begin{array}{l}0.970(0.927-1.016) \\
1.014(0.979-1.05 I)\end{array}$ & $\begin{array}{l}1.003(0.996-1.011) \\
1.003(0.996-1.011)\end{array}$ \\
\hline & $\mathrm{CO}$ & $\begin{array}{l}0 \\
1 \\
2 \\
3 \\
4 \\
5 \\
6 \\
7\end{array}$ & $\begin{array}{l}I .203(0.88 I-\mid .64 I) \\
0.96 I(0.593-I .555) \\
0.987(0.626-I .558) \\
0.674(0.309-I .472) \\
I .295(I .00 I-1.676) \\
I .096(0.763-I .572) \\
0.660(0.30 I-I .446) \\
I .167(0.859-I .587)\end{array}$ & $\begin{array}{l}1.449(1.007-2.086)^{*} \\
0.853(0.495-1.47 I) \\
1.214(0.692-2.131) \\
0.510(0.21 I-1.230) \\
I .822(1.075-3.090)^{*} \\
0.683(0.336-1.389) \\
0.715(0.318-1.609) \\
1.222(0.889-1.680)\end{array}$ & $\begin{array}{l}1.375(0.975-1.940) \\
0.907(0.652-1.261) \\
0.907(0.652-1.261) \\
1.044(0.913-1.195) \\
1.044(0.913-1.195) \\
1.044(0.913-1.195) \\
1.044(0.913-1.195) \\
1.044(0.913-1.195)\end{array}$ \\
\hline \multirow[t]{2}{*}{$>60$ years } & $\mathrm{SO}_{2}$ & $\begin{array}{l}0 \\
1 \\
2 \\
3 \\
4 \\
5 \\
6 \\
7\end{array}$ & $\begin{array}{l}1.007(0.985-1.030) \\
I .025(1.006-1.046) \\
1.004(0.98 I-1.028) \\
0.998(0.974-1.024) \\
I .009(0.987-1.032) \\
I .007(0.984-1.031) \\
0.999(0.974-1.024) \\
0.990(0.965-1.016)\end{array}$ & $\begin{array}{l}0.989(0.957-1.023) \\
1.043(1.015-1.07 I)^{*} \\
0.990(0.958-1.024) \\
0.980(0.942-1.020) \\
1.022(0.989-1.057) \\
I .004(0.969-1.039) \\
1.004(0.970-1.039) \\
0.987(0.954-1.020)\end{array}$ & $\begin{array}{l}I .003(0.974-1.033) \\
I .012(0.997-1.027) \\
I .012(0.997-1.027) \\
I .000(0.992-1.007) \\
I .000(0.992-1.007) \\
I .000(0.992-1.007) \\
I .000(0.992-1.007) \\
I .000(0.992-1.007)\end{array}$ \\
\hline & $\mathrm{CO}$ & $\begin{array}{l}0 \\
1 \\
2 \\
3 \\
4 \\
5 \\
6 \\
7\end{array}$ & $\begin{array}{l}\text { I.I } 97 \text { (0.848-I.689) } \\
1.057(0.677-1.65 I) \\
0.933(0.54 I-1.607) \\
0.609(0.248-1.496) \\
1.222(0.883-1.69 I) \\
0.813(0.42 I-1.570) \\
0.337(0.110-1.037) \\
0.912(0.533-1.56 I)\end{array}$ & $\begin{array}{l}1.419(0.948-2.124) \\
1.003(0.599-1.680) \\
1.035(0.568-1.887) \\
0.499(0.201-1.238) \\
2.005(1.126-3.568)^{*} \\
0.567(0.245-1.313) \\
0.460(0.140-1.504) \\
1.096(0.693-1.733)\end{array}$ & $\begin{array}{l}1.405(0.966-2.043) \\
0.937(0.669-1.314) \\
0.937(0.669-1.314) \\
0.948(0.780-1.153) \\
0.948(0.780-1.153) \\
0.948(0.780-1.153) \\
0.948(0.780-1.153) \\
0.948(0.780-1.153)\end{array}$ \\
\hline
\end{tabular}

Notes: *Statistically significant. ${ }^{a}$ Adjusted for trend, seasonality, temperature, relative humidity, weekdays, and holidays.

destruction in cellular immunity and epithelial changes. Pulmonary inflammation is produced through two pathways: the first is the generation of oxidative stress by free radicals that can be produced by exposure to air pollutants. The other is the reduction of immunological function through suppression of macrophages. In vitro and in vivo studies have also shown that air pollution can cause inflammation in the respiratory system, toxic responses in alveolar cells, and increased release of antiinflammatory cytokines. ${ }^{12}$

The vast amount of literature leaves little doubt about the destructive effects of air pollution on the human respiratory system. Air pollution control needs proper political management and the cooperation of multiple sectors in societies, which is weakly achieved in developing countries.

This study was the first to analyze respiratory outcomes based on age and sex in Ahvaz. One of the limitations of this study was the use of aggregated data, and the fact that its results cannot be directly generalized to the individual level. Also in this study, we were unable to control for individual confounders including occupation, eating habits, smoking, socioeconomic status, and migration that may have affected hospital admissions.

\section{Conclusion}

The results showed that air pollutants including $\mathrm{PM}_{2.5}, \mathrm{PM}_{10}$, $\mathrm{NO}_{2}, \mathrm{NO}, \mathrm{CO}$, and $\mathrm{SO}_{2}$ were associated with the risk of hospital admissions due to asthma, COPD, and bronchiectasis; in men, women, adults, and the elderly. This study emphasizes the need to reduce air pollution in Ahvaz.

\section{Details of Ethics Approval}

All patients signed a consent form while admitted and allowed their information to be used for research purposes. Researchers received de-identifiable data. The ethics clearance of the present study was acquired from the Ethics 
Committee of Ahvaz Jundishapur University of Medical Sciences (Ethics Code: IR.AJUMS.REC.1397.641).

\section{Acknowledgment}

This study was funded and supported by Ahvaz Jundishapur University of Medical Sciences with Grant No: APRD-9705.

\section{Disclosure}

No conflicts of interest were declared by the authors in this work.

\section{References}

1. Organization WH. Ambient air pollution: a global assessment of exposure and burden of disease. 2016. Available from: https://www. who.int/phe/publications/air-pollution-global-assessment/en/. Accessed July 14, 2019.

2. Guarnieri M, Balmes JR. Outdoor air pollution and asthma. Lancet. 2014;383(9928):1581-1592. doi:10.1016/S0140-6736(14)60617-6

3. Forouzanfar MH, Afshin A, Alexander LT, et al. Global, regional, and national comparative risk assessment of 79 behavioural, environmental and occupational, and metabolic risks or clusters of risks, 1990-2015: a systematic analysis for the Global Burden of Disease Study 2015. Lancet. 2016;388(10053):1659-1724. doi:10.1016/ S0140-6736(16)31679-8

4. Organization. WH. 7 million premature deaths annually linked to air pollution. Available from: https://www.who.int/mediacentre/news/ releases/2014/air-pollution/en/. Accessed July 14,2019

5. Cohen AJ, Brauer M, Burnett R, et al. Estimates and 25-year trends of the global burden of disease attributable to ambient air pollution: an analysis of data from the Global Burden of Diseases Study 2015. Lancet. 2017;389(10082):1907-1918. doi:10.1016/S0140-6736(17) 30505-6

6. Ko FW, Tam W, Wong TW, et al. Effects of air pollution on asthma hospitalization rates in different age groups in Hong Kong. Clin Exp Allergy. 2007;37(9):1312-1319. doi:10.1111/cea.2007.37.issue-9

7. Stojanovic Z, Martínez-Rivera C, Garcia-Olivé I, Radua J, AbadCapa J. Association between asthma exacerbations and air pollution in Badalona (Barcelona),(2008-2016). Eur Respir Soc. 2018: PA3970.

8. Abdolahnejad A, Jafari N, Mohammadi A, Miri M, Hajizadeh Y, Nikoonahad A. Cardiovascular, respiratory, and total mortality ascribed to PM10 and PM2. 5 exposure in Isfahan, Iran. $J$ Educ Health Promot. 2017;6.

9. Lee B-J, Kim B, Lee K. Air pollution exposure and cardiovascular disease. Toxicol Res. 2014;30(2):71. doi:10.5487/TR.2014.30.2.071

10. Kim D, Chen Z, Zhou L-F, Huang S-X. Air pollutants and early origins of respiratory diseases. Chronic Dis Transl Med. 2018;4 (2):75-94. doi:10.1016/j.cdtm.2018.03.003

11. Zhao Y, Hu J, Tan Z, et al. Ambient carbon monoxide and increased risk of daily hospital outpatient visits for respiratory diseases in Dongguan, China. Sci Total Environ. 2019;668:254-260. doi:10.1016/j.scitotenv.2019.02.333

12. Li R, Jiang N, Liu Q, et al. Impact of air pollutants on outpatient visits for acute respiratory outcomes. Int $J$ Environ Res Public Health. 2017;14(1):47. doi:10.3390/ijerph14010047

13. Goeminne PC, Cox B, Finch S, et al. The impact of acute air pollution fluctuations on bronchiectasis pulmonary exacerbation: a case-crossover analysis. Eur Respir J. 2018;52(1):1702557. doi:10.1183/13993003.02557-2017
14. Garcia-Olivé I, Radua J, Sánchez-Berenguer D, et al. Association between environmental factors and hospitalisations for bronchiectasis in Badalona, Barcelona, Spain (2007-2015). Med Clin. 2018;150 (7):257-261. doi:10.1016/j.medcle.2018.01.013

15. Ding L, Zhu D, Peng D, Zhao Y. Air pollution and asthma attacks in children: a case-crossover analysis in the city of Chongqing, China. Environ Pollut. 2017;220:348-353. doi:10.1016/j.envpol.2016. 09.070

16. Guo H, Huang S, Chen M. Air pollutants and asthma patient visits: indication of source influence. Sci Total Environ. 2018;625:355-362. doi:10.1016/j.scitotenv.2017.12.298

17. Liu F, Zhao Y, Liu Y-Q, et al. Asthma and asthma related symptoms in 23,326 Chinese children in relation to indoor and outdoor environmental factors: the Seven Northeastern Cities (SNEC) Study. Sci Total Environ. 2014;497:10-17. doi:10.1016/j.scitotenv.2014.07.096

18. Zheng X-Y, Ding H, Jiang L-N, et al. Association between air pollutants and asthma emergency room visits and hospital admissions in time series studies: a systematic review and meta-analysis. PLoS One. 2015;10(9):e0138146. doi:10.1371/journal.pone.0138146

19. Cheng M-H, Chiu H-F, Yang C-Y. Coarse particulate air pollution associated with increased risk of hospital admissions for respiratory diseases in a tropical city, Kaohsiung, Taiwan. Int J Environ Res Public Health. 2015;12(10):13053-13068. doi:10.3390/ijerph1210 13053

20. Dijkema MB, van Strien RT, van der Zee SC, et al. Spatial variation in nitrogen dioxide concentrations and cardiopulmonary hospital admissions. Environ Res. 2016;151:721-727. doi:10.1016/j.envres. 2016.09.008

21. Lelieveld J, Haines A, Pozzer A. Age-dependent health risk from ambient air pollution: a modelling and data analysis of childhood mortality in middle-income and low-income countries. lancet Planet Health. 2018;2(7):e292-e300. doi:10.1016/S2542-5196(18)30147-5

22. Quaderi S, Hurst J. The unmet global burden of COPD. Glob Health Epidemiol Genom. 2018;3. doi:10.1017/gheg.2018.1

23. Dominici F, Peng RD, Bell ML, et al. Fine particulate air pollution and hospital admission for cardiovascular and respiratory diseases. JAMA. 2006;295(10):1127-1134. doi:10.1001/jama.295.10.1127

24. Physicians ACoC. Let's unite on WorldLung Day and call for global lung health action. 2018. Available from: http://www.chestnet.org/ News/Press-Releases/2018/09/World-Lung-Day-2018. Accessed July 22, 2019 .

25. Ierodiakonou D, Zanobetti A, Coull BA, et al. Ambient air pollution, lung function, and airway responsiveness in asthmatic children. J Allergy Clin Immunol. 2016;137(2):390-399. doi:10.1016/j.jaci.2015.05.028

26. Khreis H, Ramani T, de Hoogh K, et al. Traffic-related air pollution and the local burden of childhood asthma in Bradford, UK. Int J Transp Sci Technol. 2019;8(2):116-128. doi:10.1016/j.ijtst.2018.07.003

27. Bouazza N, Foissac F, Urien S, et al. Fine particulate pollution and asthma exacerbations. Arch Dis Child. 2018;103(9):828-831. doi:10.1136/archdischild-2017-312826

28. Salimi F, Morgan G, Rolfe M, et al. Long-term exposure to low concentrations of air pollutants and hospitalisation for respiratory diseases: a prospective cohort study in Australia. Environ Int. 2018;121:415-420. doi:10.1016/j.envint.2018.08.050

29. Brakema EA, Tabyshova A, Kasteleyn MJ, et al. High COPD prevalence at high altitude: does household air pollution play a role? Eur Respir J. 2019;53(2):1801193. doi:10.1183/13993003.01193-2018

30. Phosri A, Ueda K, Phung VLH, Tawatsupa B, Honda A, Takano H. Effects of ambient air pollution on daily hospital admissions for respiratory and cardiovascular diseases in Bangkok, Thailand. Sci Total Environ. 2019;651:1144-1153. doi:10.1016/j.scitotenv.2018. 09.183

31. Gao N, Li C, Ji J, et al. Short-term effects of ambient air pollution on chronic obstructive pulmonary disease admissions in Beijing, China (2013-2017). Int J Chron Obstruct Pulmon Dis. 2019;14:297. doi:10.2147/COPD.S188900 
32. Foundation BL. What is bronchiectasis? 2019. Available from: https:/www.blf.org.uk/support-for-you/bronchiectasis/what-is-it. Accessed July 17, 2019.

33. Organization WH. Chronic respiratory diseases, bronchiectasis. 2019. Available from: https:/www.who.int/respiratory/other/bronchiectasis/ en/. Accessed July 17, 2019.

34. Hosseini-Zare N, Gholami A, Panahpour E, Jafarnejadi A. Pollution load assessment in the soil and water resources: a case study in Karun river drainage basin, southwest of Iran. Eur Online J Nat Social Sci. 2014;3(3(s)):427-434.

35. Karbassi A, Tajziehchi S, Afshar S. An investigation on heavy metals in soils around oil field area. GJESM. 2015;1(4):275-282.

36. Najmeddin A, Keshavarzi B, Moore F, Lahijanzadeh A. Source apportionment and health risk assessment of potentially toxic elements in road dust from urban industrial areas of Ahvaz megacity, Iran. Environ Geochem Health. 2018;40(4):1187-1208. doi:10.1007/ s10653-017-0035-2

37. Khaefi M, Geravandi S, Hassani G, et al. Association of particulate matter impact on prevalence of chronic obstructive pulmonary disease in Ahvaz, southwest Iran during 2009-2013. Aerosol Air Qual Res. 2017;17(1):230-237. doi:10.4209/aaqr.2015.11.0628

38. Idani E, Raji H, Madadizadeh F, Cheraghian B, Shoshtari MH, Dastoorpoor M. Prevalence of asthma and other allergic conditions in adults in Khuzestan, southwest Iran, 2018. BMC Public Health. 2019;19(1):303. doi:10.1186/s12889-019-6491-0

39. Bhaskaran K, Gasparrini A, Hajat S, Smeeth L, Armstrong B. Time series regression studies in environmental epidemiology. Int J Epidemiol. 2013;42(4):1187-1195. doi:10.1093/ije/dyt092

40. Phung D, Hien TT, Linh HN, et al. Air pollution and risk of respiratory and cardiovascular hospitalizations in the most populous city in Vietnam. Sci Total Environ. 2016;557:322-330. doi:10.1016/j. scitotenv.2016.03.070

41. Dastoorpoor M, Masoumi K, Vahedian M, et al. Associations of short-term exposure to air pollution with respiratory hospital admissions in Ahvaz, Iran. Process Saf Environ Prot. 2019;123:150-160. doi:10.1016/j.psep.2019.01.012

42. Ye X, Peng L, Kan H, et al. Acute effects of particulate air pollution on the incidence of coronary heart disease in Shanghai, China. PLoS One. 2016;11(3):e0151119. doi:10.1371/journal.pone.0151119

43. Vahedian M, Khanjani N, Mirzaee M, Koolivand A. Ambient air pollution and daily hospital admissions for cardiovascular diseases in Arak, Iran. ARYA Atheroscler. 2017;13(3):117.

44. Dastoorpoor M, Sekhavatpour Z, Masoumi K, et al. Air pollution and hospital admissions for cardiovascular diseases in Ahvaz, Iran. Sci Total Environ. 2019;652:1318-1330. doi:10.1016/j.scitotenv.2018. 10.285
45. Qiu H, Yu H, Wang L, et al. The burden of overall and cause-specific respiratory morbidity due to ambient air pollution in Sichuan Basin, China: a multi-city time-series analysis. Environ Res. 2018;167:428-436. doi:10.1016/j.envres.2018.08.011

46. Hoek G, Beelen R, De Hoogh K, et al. A review of land-use regression models to assess spatial variation of outdoor air pollution. Atmos Environ. 2008;42(33):7561-7578. doi:10.1016/j.atmosenv.2008.05. 057

47. Bayram H, Sapsford RJ, Abdelaziz MM, Khair OA. Effect of ozone and nitrogen dioxide on the release of proinflammatory mediators from bronchial epithelial cells of nonatopic nonasthmatic subjects and atopic asthmatic patients in vitro. J Allergy Clin Immunol. 2001;107(2):287-294. doi:10.1067/mai.2001.111141

48. Cai C, Xu J, Zhang M, et al. Prior SO2 exposure promotes airway inflammation and subepithelial fibrosis following repeated ovalbumin challenge. Clin Exp Allergy. 2008;38(10):1680-1687. doi:10.1111/ cea.2008.38.issue-10

49. Cheng M-H, Chen -C-C, Chiu H-F, Yang C-Y. Fine particulate air pollution and hospital admissions for asthma: a case-crossover study in Taipei. J Toxicol Environ Health A. 2014;77(18):1075-1083. doi:10.1080/15287394.2014.922387

50. Park M, Luo S, Kwon J, et al. Effects of air pollution on asthma hospitalization rates in different age groups in metropolitan cities of Korea. Air Qual Atmos Health. 2013;6(3):543-551. doi:10.1007/ s11869-013-0195-x

51. Soleimani Z, Boloorani AD, Khalifeh R, Teymouri P, Mesdaghinia A, Griffin DW. Air pollution and respiratory hospital admissions in Shiraz, Iran, 2009 to 2015. Atmos Environ. 2019;209:233-239. doi:10.1016/j.atmosenv.2019.04.030

52. Faustini A, Stafoggia M, Colais P, et al. Air pollution and multiple acute respiratory outcomes. Eur Respir J. 2013;42(2):304-313. doi:10.1183/09031936.00128712

53. Tsai -S-S, Chang -C-C, Yang C-Y. Fine particulate air pollution and hospital admissions for chronic obstructive pulmonary disease: a case-crossover study in Taipei. Int J Environ Res Public Health. 2013;10(11):6015-6026. doi:10.3390/ijerph10116015

54. Heinrich J, Schikowski T. COPD patients as vulnerable subpopulation for exposure to ambient air pollution. Curr Environ Health Rep. 2018;5(1):70-76. doi:10.1007/s40572-018-0178-z

55. DeVries R, Kriebel D, Sama S. Outdoor air pollution and COPD-related emergency department visits, hospital admissions, and mortality: a meta-analysis. J Chronic Obstr Pulm Dis. 2017;14 (1):113-121. doi:10.1080/15412555.2016.1216956

56. Li J, Sun S, Tang R, et al. Major air pollutants and risk of COPD exacerbations: a systematic review and meta-analysis. Int J Chron Obstruct Pulmon Dis. 2016;11:3079. doi:10.2147/COPD.S122282

\section{Publish your work in this journal}

The International Journal of COPD is an international, peer-reviewed journal of therapeutics and pharmacology focusing on concise rapid reporting of clinical studies and reviews in COPD. Special focus is given to the pathophysiological processes underlying the disease, intervention programs, patient focused education, and self management protocols. This journal is indexed on PubMed Central, MedLine and CAS. The manuscript management system is completely online and includes a very quick and fair peer-review system, which is all easy to use. Visit http://www.dovepress.com/testimonials.php to read real quotes from published authors. 